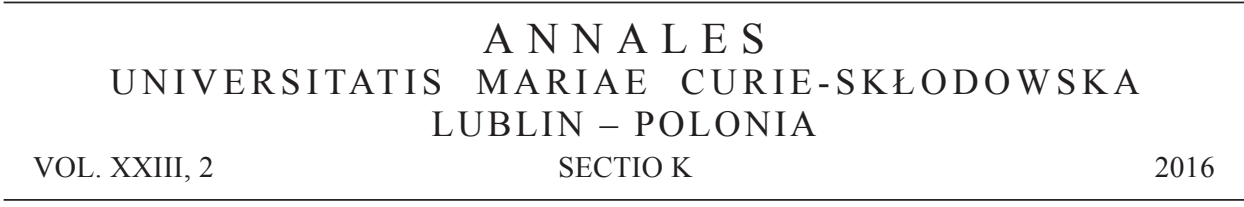

Uniwersytet w Mediolanie

IWONA DOROTA

\title{
Front włoski z czasów Wielkiej Wojny w zapiskach autobiograficznych Karola Bergera i Jerzego Alfreda Tomasza Kossowskiego ${ }^{1}$
}

Italian front of the Great War in autobiographical writings of Karol Berger and Jerzy Alfred Tomasz Kossowski

\begin{abstract}
ABSTRAKT
Wielka Wojna to „konflikt zbrojny, który radykalnie zmienił oblicze dziewiętnastowiecznego świata”. Dawny porządek spokoju i nadziei rozpadł się. Nic, co wydawało się trwałe i niezmienne, po tym wielkim starciu nie wróciło już na swoje miejsce, nie było już bowiem żadnego „swojego miejsca”. Polska w chwili wybuchu Wielkiej Wojny pozostawała pod zaborami, podzielona pomiędzy Rosję, Niemcy i Austrię, była pozbawiona własnej państwowości. Polacy, nie mogąc o sobie niezależnie stanowić, zostali przymusowo wcielani do wojska zaborcy w zależności od terytorium, jakie zamieszkiwali; zmuszono ich do przywdziania uniformów obcych, zaborczych armii, w konsekwencji musieli do siebie strzelać i wzajemnie się zabijać. Wojna 1914-1918 to jednak pierwszy konflikt, w którym bezpośrednio zaangażowali się wszyscy trzej zaborcy, w związku z czym zrodziła ona wśród Polaków głęboką nadzieję na odzyskanie niepodległości. Służba w armii austro-węgierskiej początkowo nie przynosiła ujmy Polakom ze względu na prowadzoną przez Wiedeń politykę pozwalającą na zachowanie w jakimś stopniu „narodowego statusu”, ale sytuacja zmieniła się drastycznie wraz upływem czasu. Karol Berger i Jerzy Alfred Kossowski, uczestnicy i świadkowie walk na froncie włoskim, w swoich autobiograficznych zapisach przedstawili nam szczegółowe opisy tego frontu, które obnażają tragedię walk tam rozgrywanych, ale jednocześnie ujawnili okrucieństwo samej wojny. Uświadamiamy sobie jednak, że Polacy, a konkretnie Berger, czynili wszystko, aby oswoić tamtą straszną wojnę i nadać jej w miarę możliwości jakieś ludzkie oblicze, stworzyć choćby surogat życia

1 Artykuł ten jest w znacznej mierze zmienioną i poszerzoną wersją referatu „Il fronte italia non elle descrizioni dei polacchi combattenti nell'esercito austro-ungarico" wygłoszonego na kongresie międzynarodowym we Włoszech „Grande Guerra. Trame disperse. Esperienzedi viaggio, di conoscenza e di combattimento nel mondo della Grande Guerra (1914-18)", Fano-Senigallia-Castebellino (28-29-39) listopad 2014.
\end{abstract}


i normalnego współistnienia. Dzięki Kossowskiemu i jego działaniom podczas pierwszej wojny światowej nie doszło do zbombardowania Wenecji, a dokładniej samego jej serca, tj. Placu św. Marka z jego Bazyliką. Zapiski autobiograficzne, o których mowa, pokazują, jak bardzo obu uczestnikom wojennych zmagań drogi był mit Italii i jak wiele robili, aby nie pozwolić się zniszczyć machinie zła. Zarówno przez drobne gesty (postawa Bergera) czy spektakularne działania (postawa Kossowskiego) czynili wszystko, aby opanować „nieopanowane” okrucieństwo wojny.

Słowa kluczowe: front włoski, Wielka Wojna, Karol Berger, Jerzy Alfred Tomasz Kossowski

\section{WSTĘP}

Temat traktujący o Wielkiej Wojnie w kontekście działań Polaków, tak w armii austro-węgierskiej, jak i szczególnie na froncie włoskim, sytuuje się na płaszczyźnie o niejasno zaznaczonych konturach interpretacyjnych. Zapiski autobiograficzne uczestników frontowych działan - Karola Bergera i Jerzego Alfreda Tomasza Kossowskiego - nie zostały poddane pogłębionej refleksji na gruncie polskim, tym bardziej zagranicą nie usytuowano ich w szerszym historyczno-politycznym kontekście.

Podjęty temat badawczy, nowatorski pod tym względem, ma na celu wyartykułowanie obecności polskiego żołnierza na froncie włoskim w jego strategicznym punkcie (pierwsza linia frontu włoskiego), jego osadzenie w perspektywie politycznych uwarunkowań i historycznych konotacji, a ponadto ukazanie znaczenia działań tychże uczestników w kontekście podejmowanych czynności operacyjno-wojskowych na obszarze frontu włoskiego i nie tylko. Celem artykułu pozostaje także ustalenie, czy sposób prezentacji frontu włoskiego przez polskich uczestników wydarzeń (Berger, Kossowski) wpisuje się w utrwalony w literaturze przedmiotu sposób jego prezentacji, czy też stanowi swoiste novum, oraz co ewentualnie świadczy o istocie, wartości tychże relacji, oczywiście oprócz wartości dokumentalnej, niezaprzeczalnej a priori?

Polska w chwili wybuchu Wielkiej Wojny pozostawała od 1795 r. pod zaborami, podzielona pomiędzy Rosję, Niemcy i Austrię, była pozbawiona własnej państwowości. Polacy, nie mogąc o sobie niezależnie stanowić, byli przymusowo wcielani do wojska zaborcy w zależności od terytorium, jaki zamieszkiwali. W ten sposób do ponad czteromilionowej grupy emigrantów dołączyły następne miliony i tysiące wcielonych do obcych armii (ponad $3 \mathrm{mln})^{2}$ i ewakuowanych żołnierzy (360 tys. z samej tylko Galicji, a 1,2 mln z Królestwa) [Gilbert 1994: 101; Lewandowski 1991: 154; Kucharski 1991: 50-71]. Dramat Polaków tamtego czasu polegał też na tym, że zmuszeni do przywdziania uniformów obcych, zaborczych armii, walcząc

2 M. Gilbert podał ponadto, że ,na frontach pierwszej wojny światowej walczyło około 2 miliony Polaków, z czego poległo 450 tysięcy". 
za carską, niemiecką czy habsburską dynastię, tj. za Romanowów, Hohenzollernów czy Habsburgów, musieli do siebie strzelać i wzajemnie się zabijać.

Wojna 1914-1918 to jednak pierwszy konflikt, w którym bezpośrednio zaangażowali się wszyscy trzej zaborcy, w związku z czym zrodziła ona wśród Polaków głęboką nadzieję na odzyskanie niepodległości.

Służba w armii austro-węgierskiej początkowo nie przynosiła ujmy Polakom ze względu na prowadzoną przez Wiedeń politykę pozwalającą na zachowanie w jakimś stopniu „narodowego statusu” [Koźniewski 1963: 242]. Austriacy godzili się, by Polacy formowali ,wyłącznie własne oddziały wojskowe, na przykład legiony” w swej wielonarodowościowej armii ${ }^{3}$ [Koźniewski 1963: 242; Batowski 1982: 21-49]. 5 listopada 1916 r. ukazał się akt cesarzy określający ich stanowisko wobec polskich aspiracji niepodległościowych. Austria i Niemcy obiecali namiastkę ,niepodległości” Polski, gra szła bowiem o polskiego rekruta, którego zasoby były oceniane na 1,4 mln osób [Wyszczelski 2001: 25]. Sytuacja skomplikowała się jednak z chwilą, kiedy znaczna część polskich oficerów i żołnierzy odmówiła złożenia przysięgi na wierność cesarzowi Franciszkowi Józefowi, a przede wszystkim cesarzowi Niemiec Wilhemowi II; chodzi o tzw. „,kryzys przysięgowy”, do którego doszło w momencie, kiedy Włochy wypowiedziały wojnę cesarstwu, tj. 24 maja 1915 r. [Cygan 2005: 6-7]. Austriacy, znając niechęć Polaków do prowadzenia ewentualnych działań zbrojnych właśnie z Włochami i mając jednocześnie świadomość, że nie należą one do łatwych, a wprost przeciwnie, na pierwszą linię frontu włoskiego skierowali przymusowo oddziały złożone właśnie z samych Polaków, by wymienić pułki z Nowego Sącza (20 pułk), z Tarnowa (57 pułk), a także z Wadowic (56 pułk). Inne zaś dołączyły do nich w miarę, jak wymagała tego potrzeba chwili. Większość polskich pułków brała jednak udział we wszystkich walkach nad rzeką Socza.

W tamtym okresie jednak jedynie wojna z Rosją nosiła dla Polaków znamiona wojny narodowowyzwoleńczej i przybliżała do odzyskania wolności. Oficerowie polscy służący w armii austro-węgierskiej monitowali więc do swych przełożonych w Wiedniu o przeniesienie ich pułków na rosyjską linię frontu, co sprawiło, że zyskali oni status podejrzanych politycznie. W sytuacji zaś kiedy całe pułki polskie, znane z waleczności i męstwa, zostały przez dowództwo austriackie przerzucane z frontu rosyjskiego na front włoski, którego znaczenie od 1917 r. zdecydowanie wzrosło, doszło do groźnych w skutkach demonstracji ${ }^{5}$. Dowództwo austriackie straciło zaufanie do Polaków, co z kolei dało podstawy do stworzenia w wojsku zalążków antyaustriackiej konspiracji niepodległościowej, np. w 20 pułku galicyjskim. W tym

3 H. Batowski uszczegółowił, że w skład Austro-Węgier wchodziło 18 odmiennych jednostek terytorialnych, z czego tylko 3 miały charakter etnicznie czysto niemiecki. Polacy zamieszkiwali Austro-Węgry w liczbie $4,9 \mathrm{mln}$, co stanowiło $9,9 \%$.

4 Kryzys, o którym mowa, miał miejsce w lipcu 1917 r. i przyniósł kres Legionów, w następstwie którego legioniści-poddani austriaccy zostali wcieleni do c.k. armii.

5 Odnotowywano przypadki obrzucania granatami ręcznymi baraków, w których stacjonowało dowództwo korpusu austriackiego. 
też okresie znaczna liczba pułków złożonych z samych Polaków została wysłana na front włoski, by wymienić tylko niektóre z nich: 1, 2, 4, 5, 6 pułki piechoty, 1 pułk ułanów, 1 pułk artylerii, 1 kompania saperów nr 1 i skład sanitarny 1 brygady w sumie 148 oficerów i 3467 żołnierzy [Snopko 2008: 330].

Sytuacja diametralnie się zmieniła w lutym 1918 r., kiedy Austro-Węgry zaczęły się borykać z ogromnym kryzysem aprowizacyjnym. W związku z czym na mocy traktatu brzeskiego zdecydowali się na daleko idące ustępstwa terytorialne wobec Ukrainy kosztem polskich interesów narodowych [Snopko 2008: 330]. Decyzje te potraktowano jako zdradę ze strony Austrii i wywołały one niekończącą się falę protestów, także wśród Polonii włoskiej. Emocje były tak wielkie, że żołnierze Legionów Polskich ( 2 brygada) zdecydowali się ,na zaprzestanie walk u boku Austrii. Powstaje też się projekt przedarcia się przez front pod Rarańczą i połączenia z Armią Polską na Wschodzie", co w konsekwencji doprowadziło do walk zbrojnych właśnie z armią austro-węgierską [Solek 1988: 250]. Za ten zbrojny incydent wielu oficerom i żołnierzom polskim wymierzono karę śmierci, poddani zostali też surowym represjom, przewożono ich do obozów i wytaczano procesy [Hupka 1936: 355-360]. Ułaskawieni, dzięki ogromnej mobilizacji opinii publicznej, zostali wysłani z obozów internowania właśnie na linię frontu włoskiego. Pierwsze transporty legionistów ruszyły już w końcu marca 1918 r. Oni sami, szczęśliwi, bo oswobodzeni, w miarę zbliżania się do granicy włoskiej odczuwali coraz większą ,głuchą wściekłość” [Popiołek 1928: 395-396].

Transporty legionistów pod eskortą kierowano z obozów do Udine. W tym okresie ogółem na front włoski trafiło stu oficerów i trzy tysiące żołnierzy z rozwiązanego Polskiego Korpusu Posiłkowego ${ }^{6}$ [Stępnik 1997: 11-62]. Początkowo byli kierowani do tzw. grupy „P” (Polen), w której przeprowadzano szkolenia rekruckie. Grupa składała się z dziewięciu podgrup rozlokowanych w miasteczkach Friuli-Venezia Giulia: Attimis, Colloredo di Prato, Faedis, Magredis, Ravosa, San Daniele del Friuli, Variano, Villaorba [Snopko 2008: 383]. Następnie żołnierze byli kierowani do poszczególnych pułków (Regimentsausbildungsgruppen) podległych 2 armii. Wyższe dowództwo austro-węgierskie odnosiło się do Polaków z dużą nieufnością, by nie powiedzieć z wrogością. Niemiecki generał von Linsingen otrzymał bowiem wyraźny rozkaz Berlina, aby zlikwidować II Korpus Polski Stankiewicza stacjonujący we Włoszech [Snopko 2008: 128]. Dowództwo austro-niemieckie obawiało się, że Polacy zdradzą i przejdą w całości na stronę Włochów, dlatego też niespodziewanie zostali wycofani ze wszystkich dywizji i sformułowano z nich batalion „A" we wsi Ceggia, a następnie przeprowadzono pod eskortą do San Fior di Sotto i otoczono ścisłym nadzorem oddziałów węgierskich, którzy mieli wykonać ewentualny rozkaz całkowitej ich zagłady.

Legioniści coraz częściej nawiązywali kontakty z Włochami i przechodzili na ich stronę. Co więcej, polska kadra oficerska rozważała ewentualność całościowej dezercji

6 Decyzję o przekształceniu Legionów Polskich w Polski Korpus Posiłkowy podjął cesarz Franciszek Józef 20 września 1916. 
pułków złożonych z Polaków na stronę włoską w ramach zamierzonego austriackiego przewrotu, nad którym pracowała wewnątrz armii austro-węgierskiej tajna polska organizacja „Wolność 1918”. Brała ona także pod uwagę decyzję o wystąpieniu zbrojnym przeciw Austrii, jak podał Jerzy Giza w swej cennej książce [Giza 2011: 99]. Włosi ze swej strony starali się osłabić zdolność bojową wojsk austro-węgierskich przez działania propagandowe w pułkach słowiańskich. Odcinki frontu zajmowane przez Polaków były zasypywane ulotkami w języku polskim [Horoszkiewicz 1938: 34-36].

Modris Eksteins, profesor historii na uniwersytecie w Toronto podkreślił, że człowiek w Wielkiej Wojnie „był podróżnikiem, który na rozkaz przekroczył granicę egzystencji i tam na peryferiach »żył « w wyjątkowy sposób, na krawędzi ziemi niczyjej, na marginesie normalnych pojęć [...] Żołnierz był zdany na karmienie się własną wyobraźnią" [Eksteins 1996: 239]. Należy dodać, że często była to wyobraźnia okaleczona, zraniona, ale i bohaterska, stale napotykająca na rzeczywistość okrutną, wrogą, nierzadko niepozbawioną poruszających uniesień. Eksteins stwierdził, że „w literaturze na temat wojny często pada stwierdzenie, że to już nie ludzie tworzyli wojnę, lecz wojna tworzyła ludzi. Wobec dominującej techniki wojennej - karabinów maszynowych, artylerii, gazu - pojedynczego żołnierza przytłaczało poczucie bezbronności i bezradności"7 [Eksteins 1996: 239; Święch 2003]. Bez względu na to, jak słuszna wydaje się ta teza, w przypadku dwóch postaci, uczestników Wielkiej Wojny - Karola Bergera i Jerzego Alfreda Tomasza Kossowskiego - teza ta w swej tragicznej wymowie zostaje osłabiona, a jej pesymistyczna artykulacja zostaje odsunięta na dalszy plan, gdyż to, co uderza w opisach, pamiętnikach czy zapiskach autobiograficznych Polaków, to próba - choć nie zawsze do końca udana, to jednak czyniona - wydarcia wojnie tego, co można było jej wydrzeć, choćby namiastki dobra, życzliwości; to dążenie do ocalenia jej ludzkiego aspektu, oswojenia wojny, jej odmiany. To czynne, aktywne uczestnictwo, pełne trudu i poświęcenia, a nie jedynie bierne poddanie się machinie zła. To próba wyrażenia „niewyrażalności wojny” [Olszewska 2004: 22].

W przededniu wybuchu Wielkiej Wojny całe terytorium Austro-Węgier było podzielone na 16 okręgów korpusowych (Korpskommando). Każdy obywatel wraz z ukończeniem 21. roku życia był powołany do służby wojskowej. Szczególną grupę poborowych stanowili tzw. jednoroczni ochotnicy, maturzyści bądź absolwenci

7 J. Święch wskazał na antyhumanistyczny aspekt cywilizacji, która głosząc triumf postępu i techniki, odbierała jej „ludzkie oblicze” i doprowadzała do alienacji idei wojny jako zjawiska kulturowego. 
szkół wyższych [Giza 2011: 39]. Ich służba zaczynała się dwumiesięcznym okresem rekruckim, a kończyła egzaminem uprawniającym do zostania oficerem.

Jednym z jednorocznych był właśnie Karol Berger, autor autograficznych zapisków pod znamiennym tytułem Piekło pod Trzema Krzyżami. Na Podgorze. Garść wspomnień frontu włoskiego, który opisał swe doświadczenia służby w armii cesarsko-królewskiej, począwszy od chwili poboru, tj. maja 1915 r. Zapiski, początkowo sporządzane z dala od linii frontu, ujawniają dogłębną słabość armii austro-węgierskiej, zarówno pod względem wyposażenia w mundury, amunicję, higienę czy trudności w komunikowaniu, jak również obnażają machinę korupcji, stronniczości i braku skuteczności ze strony niższych rangą dowódców armii.

Należy pamiętać, że w czasie trwania Wielkiej Wojny 75\% całej męskiej ludności zamieszkującej Austro-Węgry zostało powołanych do wielonarodowościowej armii, trudno więc chociażby dlatego mówić o profesjonalizmie wszystkich jej dowódców. Jednak to nie w procentowości, lecz w różnorodności etnicznej, a co za tym idzie i językowej należy upatrywać tych celowych zaniedbań, na które wskazał Berger. Francja i Niemcy powołały bowiem największą liczbę swej męskiej części społeczeństwa do służby, tj. $80 \%$, i przypadki tego typu nie miały miejsca na tak szeroką skalę ${ }^{8}$ [Winter 2007: 447-449].

Karol Berger został skierowany na front włoski w lutym 1916 r., przydzielony do 4 kompanii, której komendantem był porucznik Havliczek. Wraz z batalionem udał się do Podgory, miejsca, gdzie „śmierć zbiera hojne żniwo” [Berger 1930: 44].

Teatr frontu włoskiego wymaga pewnego przybliżenia, pozwoli to bowiem we właściwy sposób usytuować kartograficznie pozycję zajmowaną przez Bergera, a także pomoże w określeniu znaczenia tegoż frontu dla generała Luigiego Cadorna, głównego dowódcy wojsk włoskich.

Italia prowadziła walki z armią austro-węgierską główne na dwu obszarach, a mianowicie: w Alpach na wysokościach przekraczających niejednokrotnie $2500 \mathrm{~m}$ i na drugim obszarze, usytuowanym w pobliżu gór Krasu i rzeki Soczy (od Tolmino, Plezzo) aż po morze. Mamy tu do czynienia z dwoma różnymi ukształtowaniami terenu, de facto różnymi frontami i różnymi wojnami, jak podkreśliła Nicola Labanca [Labanca 2007: 448]. Pierwsze z działań wojennych, określane mianem „białej wojny”, ,wojny jedynej w swoim rodzaju” czy unicum owianego tajemnicą, w niezwykle inspirujący sposób zawładnęło wyobraźnią filmową i artystyczną tamtego okresu, głównie ze względu na piękno gór określanych mianem ,prawdziwego muzeum na otwartej przestrzeni" [Leoni 2007: 237-246; Alonge 2007: 663-675; Fabi 2007: 536].

8 Włochy podobnie zwerbowali ok. 75\% społeczeństwa, zaś liczba ta w przypadku Wielkiej Brytanii, Serbii i Turcji kształtuje się na poziomie 50-60\%, Rosja natomiast powołała do armii zaledwie $40 \%$ swej męskiej ludności. Jay Winter przeanalizował też wzajemne powiązania na płaszczyźnie powołań do armii i strat w zasobach ludzkich na polach walki, a także rozpatrzył ten problem w kategoriach: zaginionych, jeńców, rannych i zabitych, w kontekście wszystkich krajów uczestniczących w Wielkiej Wojnie. Godne odnotowania są dane dotyczące Austro-Węgier, które kształtują się następująco: 9000000 (wcieleni do wojska i zaginieni), 1100000 (zabici), 3620000 (ranni), 2200000 (więźniowie). 
Fritz Weber podkreślił, że „Wojna w Dolomitach, te walki pomiędzy niewielkimi grupkami żołnierzy, porozrzucanymi pomiędzy niebem a ziemią, tworzą przypadek jedyny w swoim rodzaju w historii” [Leoni 2007: 237]. Miejsce w pobliżu gór Kras natomiast, czyli tam, gdzie znajdował się Berger, to obszar, gdzie zmasowano prawie wszystkie ataki włoskie, gdyż tamtędy prowadziła droga w kierunku Wiednia i głównych ośrodków cesarstwa Austro-Węgier. Zmasowane ataki wojsk włoskich w tym obszarze były więc podyktowane istotną strategicznie rolą tego terenu, jak również doniosłością militarną i taktyczną tego frontu. Tu istniała bowiem największa możliwość przerwania austriackiej linii oporu ze względu także na ukształtowanie terenu.

Karol Berger wyposażył nas w dokładny opis topograficzny miejscowości, w której się znajduje: „Po lewej stronie ruiny miasteczka Lucinico, po drugim brzegu ruiny miasteczka St. Andre. Hen w dali płaskowyż Doberdo. Przed nami wielka nizina, ciągnąca się ku morzu, które na horyzoncie patrzy na nas swemi wodami. Wśród falistego terenu, pokrytego kikutami drzew, wiją się drogi, na których widać samochody ciężarowe, dowożące naszym sąsiadom [tzn. Włochom] materiał wojenny” [Berger 1930: 44]. ,Zasieki włoskie dotykają austriackich [...] podchodzą aż pod nasze pozycje. Tam usadowili się Włosi, wybetonowali sobie tu małą twierdzę, nazwaną przez nas »Sandburg«. Stąd prażyli nas nieustannie" [Berger 1930: 47]. „Patrzę ja przez dziurę na sąsiada i konstatuję, że ich pozycje są o wiele lepsze. - Tak szybko z nimi tej wojny nie wygramy, pomyślałem sobie" [Berger 1930: 47-48].

Informacja o lepszej pozycji strategicznej Włochów, podana przez Bergera, nie znalazła potwierdzenia we włoskiej literaturze przedmiotu [Labanca 2007: 222-229]. Może jednak wynikać z faktu ogromnej przewagi liczebnej, jaką posiadali Włosi w stosunku do armii austro-węgierskiej, a kształtującej się początkowo na poziomie $3: 1$, a następnie $2: 1^{9}$ [Labanca 2007: 224].

Berger niejednokrotnie więc podkreślał, że „front włoski, to front gorący”, który w niczym nie ustępuje temu francuskiemu [Berger 1930: 43]. Mógł się o tym przekonać zaraz po objęciu swego stanowiska. W jego opisach jak ritornello powraca słowo „piekło”: „Ciemno wszędzie, błota w rowach po kostki” [Berger 1930: 46]. „Sunę jak duch, bo głośniejszy krok się nie opłaca. Sąsiad bliski, posyła więc zaraz na głowę granat. Ludzie przylepiają się do otworów strzelniczych, otulają się w celty, wysuwają przez dziurę karabin gotowy do strzału. Stoją w dwójkach co kilka kroków [...] Włoski reflektor niepokoił nas. Rzucał snopy światła na naszą pozycję i gdy człowieka złapał, trza się było przylepić do ściany i ani ruszyć, bo od razu padały granaty ręczne lub małe miny. U nas była względna cisza w tę noc. Granaty

9 Należy pamiętać, że rząd włoski powołał pod broń z liczącej wówczas 37 milionów społeczności nieprzeliczone grupy osób, i tak z klas 1886-95 liczących ok. 5 milionów powołano do służby ponad 2 miliony mężczyzn, z klas 1882-85 liczących mniej niż 2 miliony powołano ponad 800 tysięcy mężczyzn, z klas 1874-81 liczących ponad 3 miliony powołano ponad 1,5 miliona mężczyzn. Dane te uświadamiają nam ogrom wysiłku społeczeństwa włoskiego, dla przypomnienia w czasach pokoju w armii służyło ok. 300 tysięcy żołnierzy. 
padały co parę minut, a dla urozmaicenia w przystankach grzmociły miny. Za to na Doberdo i Osławii był ciągły taniec" [Berger 1930: 46].

Włosi zaadoptowali określony system ostrzeliwania podczas trwania wojny, oczywiście nie dotyczył on ofensyw: „Od rana do wieczora częstowały nas małe działa. Zwane przez nas »szprycami«, z równiny Lucinico. Granaty padały tuż u wejścia do naszych kawern. Dla urozmaicenia błąkały się tu i kokosze. Potem do jedenastej nastawał względny spokój, powiadaliśmy, że artylerzyści włoscy mają drugie śniadanie. Koło jedenastej przybywała do nas menaż. Naturalnie, gdzieżby o tem nie wiedzieli Włosi? Przecież mieli tak doskonale zorganizowaną służbę wywiadowczą [...] Kiedy więc kotły stanęły u wejścia do kawern i momaki z szalkami spieszyli po swoje porcje, sąsiedzi zaczęli nam zupę przysalać. Naturalnie teraz padały i ciężkie pociski, a wiernie towarzyszyły im i mniejsze kalibry. Nieraz zupa zupełnie ochłodła, bo z powodu ognia nie można było dojść do kuchni. Dość gęsto się też zdarzało, że byliśmy bez jedzenia [...] Pod wieczorem, kiedy znów kuchnie nadchodziły, zaczynał się koncert. Trwał już teraz z malutkiemi przerwami do rana" [Berger 1930: 82-83].

Samo nazewnictwo, jakie zastosował Berger: zamiast wróg czy Włoch po prostu sąsiad, wskazuje na próbę oswojenia wojny, nadania jej w miarę ludzkiego oblicza, stworzenia namiastki życia, egzystencji w normalnych warunkach ludzkiego współistnienia. Podobnie dzieje się z nazewnictwem sprzętu wojennego, aparatury, które podczas Wielkiej Wojny zajmują miejsce człowieka ${ }^{10}$ [Rozmus 2013: 9].

W momencie kiedy autor określił sprzęt mianem „kokoszki” czy „,cielątka”, ze strasznego narzędzia niosącego śmierć, zadającego ból i przyprawiającego o rozpacz sprowadził je do roli elementu kultury agrarnej, tak bliskiej zarówno kulturze polskiej, jak i austriackiej, które nie może szkodzić, a w tym wypadku przynajmniej nie powinno. Może chodzi tu o jakiś rodzaj ,zaklęcia rzeczywistości” przez słowo i uczynienia jej sobie bliższą, nadania jej bardziej ludzkiego oblicza czy chociażby znaczenia z rzędu animalis: ,Włosi bili małemi minami, które powszechnie nazywano »kokoszkami«. Głowa wielkości pięści była wypełniona materiałem wybuchowym. Od głowy prowadziła rurka do $3 \mathrm{dm}$, zakończona ognistym ogonem. Małe było to licho, ale niebezpieczne. Rozpryskiwało się na setne kawałki i porządnie raniło" [Berger 1939: 48].

Ta niekończąca się walka wynikała z przyjętej przez generała Cadornę taktyki, u podstaw której leżało dążenie do zwycięstwa wszystkimi możliwymi sposobami i za wszelką cenę, nie bacząc na ogrom strat w ludziach, w sprzęcie i co za tym idzie - strat finansowych. Uparte dążenie do pójścia naprzód, mimo braku osiągniętych celów, przysparzało generałowi coraz większą liczbę wrogów wewnątrz, i nie prowadziło na polu walki do żadnych zasadniczych rozwiązań. Cztery ofensywy nad Soczą przeprowadzone według starej zasady walki frontalnej nie przechyliły

10 Należy mówić o apogeum mechanizacji podczas starć wojennych. Pierwszą wojnę światową uznaje się za konflikt totalny, wojnę materiałową, starcie maszyn, jak podkreślił J. Rozmus. 
szali zwycięstwa na żadną ze stron"1 [Labanca 2007: 449; Liddell Hart 2014: 274]. Potwierdza to w pełni tekst Bergera, który oddaje piekło tego „piekielnego” miejsca.

Zapiski Bergera przynoszą dokładnie informacje o piątej włoskiej ofensywie pod Soczą rozpoczętej 11 marca 1916 r. i zakończonej 16 marca 1916 r., która zbiegła się z zakończeniem obecności włoskiej w Albanii.

Z punktu widzenia Italii rok 1916 to „bardzo ciężki rok” pod wieloma względami, jak podkreśliła Nicola Labanca w swej pracy La guerra sul fronte italiano e Caporetto [Labanca 2007: 449]. Pierwszy z powodów to chociażby ten, że nadzieje na szybkie i zwycięskie zakończenie wojny spełzły na niczym. Cztery ofensywy nad Soczą nie zmieniły w radykalny sposób oblicza tego frontu. Co więcej, doprowadziły one do ogromnych strat w elitarnym jeszcze wtedy dowództwie wojska włoskiego i jego składzie oficerskim. Coraz częściej należało uciekać się też do zaostrzonej dyscypliny wśród żołnierzy wobec nasilających się przypadków dezercji (także Berger poświęca temu zagadnieniu sporo miejsca), gdyż aspekt wewnętrznej propagandy w armii włoskiej o wysokim jeszcze wtedy stopniu analfabetyzmu zawiódł zupełnie [Labanca 2007: 449; Guerrini, Pluviano 2004].

Karol Berger w swym tekście o niekwestionowanych walorach literackich dostarczył wyczerpujących informacji o piątej ofensywie, która zakończyła się, jak poprzednie, brakiem definitywnego rozstrzygnięcia: „Zaczęła się piąta włoska ofensywa. W pierwszym dniu to było po staremu. Taka sobie zwyczajna strzelanina granatami, szrapnelami i minami. Drugiego dnia [...] koło południa strzelanina przechodzi w ogień huraganowy [...]. Włosi i na prawo, i lewo częstują nas granatami ręcznymi [...]. Ogień artylerii wzmaga się [...]. Alarm. Wybiegamy z bezpiecznego schronienia i w biegu wpadamy do pierwszej linii. Na lewym skrzydle gęsta strzelanina karabinowa, ciągle wybuchy granatów ręcznych. Tam wre zażarta walka [...]. Wyrywamy naprzód w przypuszczeniu, że teraz nastąpi generalny atak. Usadawiamy się w lejach $[\ldots]$ bez przerwy wyrzucamy rakiety. Przecudny fajerwerk. Całemi salwami wylatują kolorowe rakiety wtóre, rozpryskują się w drobne gwiazdki i długą smugą z sykiem spadają na ziemię, przeoraną tysiącami granatów różnego kalibra. [...] Nagle koło dziewiątej wieczorem po względnej ciszy istne piekło rozwarło się nad nami. Ciemna noc. Deszcz zaczął lać. Artyleria po krótkim spoczynku zerwała się na nowo. Rzygała na nas tysiącami granatów. Eksplozje następowały po sobie tak szybko, że ucho nie mogło złapać ich następstwa i straszliwy trzask zlewał się w jeden przeraźliwy chaos, podsycany terkotaniem karabinów maszynowych oraz trzaskiem karabinów ręcznych. Rozwalana ziemia zasypuje nas ciągle. Kurczymy się w sobie, aby być jak najmniejszym celem. Koło uszu warczą odłamki granatów i skał. Czerwony błysk pękających pocisków oślepia. Dym zaczyna dusić, na głowy zarzucamy celty [...] Przed sobą widzimy szturmowe oddziały włoskie, które

11 Natomiast kolejna, szósta ofensywa nad Soczą zakończyła się zdobyciem Gorycji przez Włochów, gdyż podczas jej trwania przewaga liczebna wojsk italskich była druzgocąca - na 16 dywizji włoskich przypadało zaledwie 6 dywizji armii austro-węgierskiej. 
idą do ataku. Atak odparty. Włosi mają straty. Pozostawiają rannych i zabitych na pobojowisku i bezładnie wycofują się" [Berger 1930: 56].

Ten wyczerpujący opis Bergera, oprócz swojej niekwestionowanej wartości historycznej, dotyka także istotnego problemu, jakim jest śmierć ,innych” na polu walki. Podążając za tokiem myślenia Anny Duménil, uświadamiamy sobie, że tak naprawdę nie chodzi tylko o całe szeregi walczących na froncie żołnierzy, lecz także o swego rodzaju ich nieuniknioną transformację w „społeczności w żałobie” i „,społeczności żałobne”. Tym bardziej że śmierć nie jest tu jedynie czymś ,abstrakcyjnym i odległym", ale staje się faktem, w którym każdy pojedynczy człowiek „uczestniczy” i jest „w nim obecny”. Dotyczy ona bowiem osób wzajemnie za sobą powiązanych, przynależących, chociażby tylko do tej samej dywizji czy batalionu [Duménil 2007: 209-210]. Co więcej, doświadczenie śmierci w swej tragicznej, „gwałtownej” wymowie ponawia się nieustannie, doprowadzając tym samym do „zakorzenienia się” okrucieństwa na polu walki, które generuje strach i lęk. Śmierć w ogniu walk pozbawia możliwości godnego pochówku, a nierzadko odbiera nadzieję na jego jakąkolwiek formę, stąd należy mówić o szeroko pojętym ,wyobcowaniu społeczno-kulturalnym” walczących, co prowadzi do naruszenia, a nawet ,zatracenia mikrostruktury jedności i ciągłości” [Duménil 2007: 209-210].

Inną postacią, która walczy na froncie włoskim, jak zobaczymy z wyjątkowo spektakularnym sukcesem, jest Jerzy Alfred Tomasz Kossowski. Urodzony 18 lipca 1889 r. we Lwowie, studiował prawo i historię sztuki na Uniwersytecie Jana Kazimierza. Kossowski w 1912 r. został przymusowo wcielony do wojska austriackiego, w którym skończył szkołę podchorążych. W chwili wybuchu pierwszej wojny został zmobilizowany i walczył na frontach rosyjskim, a następnie włoskim. Opis walk na tym ostatnim zawierają zapiski autobiograficzne Zielona kadra. Kossowski skoncentrował swą uwagę na wielu istotnych problemach tamtego okresu, m.in. na sytuacji dezerterów, problemach miasteczka Ceggia, postaci bohaterskiego Giacomy Bicaraniego, który przyczynił się do zwycięstwa wojsk włoskich nad rzeką Piave [Kossowski 1963: 195]. Autor dostarczył nam też cennych informacji z pierwszej linii frontu włoskiego, zaprezentował dramatyczne sytuacje i wydarzenia z pola walki, ukazał czytelnikowi to, czym była Wielka Wojna. Nowela Kawerna $n r 7$ jest tego tragiczną egzemplifikacją. Bojowa linia frontu „szła z góry od Isonzy przez białe, rozpalone skały Krasu i kończyła się w morzu pod zamkiem Duino”, znajdowała się w pobliżu ,cmentarza Selo, w tunelach mozolnie wierconych, ociekających wodą” [Kossowski 1963: 122].

„Jak Kras długi i szeroki, w każdym leju, zapadłym aż do żółtej, dobrej ziemi, siedziały oddziały głupio karnej austriackiej armii. Wgrzebywały się u dna dolinki poziomo w skałę i póty ryły, i kuły, póki nie wyrwały w niej tunelu idącego podko- 
wą, której drugi wylot miał im dać ocalenie w razie zawalenia pierwszego. Były to jakby gniazda pszczół skalnych, do których wejścia były zasłonięte workami piasku i gliny. Żyliśmy w tych gniazdach tygodniami i urządzaliśmy je jak najprzystojniej” [Kossowski 1963: 122].

Właśnie konstrukcje tego typu i usytuowania armii austro-węgierskiej wśród przestrzeni górskich stanowiły o jej sile. Miejsca takie były dla wojsk włoskich przeszkodą nierzadko nie do pokonania. Wielka Wojna była określana przez to „wojną rowów” "wojną okopów”"12 [Audoin-Rouzeau 2007: 231-236].

Jak podał Kossowski, w najmniej dostępnych miejscach, we wgłębieniach przygotowywano fortyfikacje, w których stacjonowały nawet całe dywizje. To były niemal ,jamy wilków” bądź jak je określił Kossowski, „gniazda pszczół skalnych” [Audoin-Rouzeau 2007: 231].

Poważnym mankamentem tego, zdawałoby się bezpiecznego, usytuowania była jednak w tym wypadku obecność cmentarza. Każdy powiew przynosił w stronę armii „ckliwą trupią woń”: „Co kilka dni wysyłano całe ekspedycje ludzi z łopatami i z formaliną w nosie, by grzebały po raz setny, odgrzebane i na światło boże po raz setny wyrzucone, trupy” [Kossowski 1963: 123]. „Przykryte świętą ziemią w nocy, już rano lub w południe bluźniły swą nagością w słońcu i samą swą obecnością broniły Włochów skuteczniej niż gazy trujące. Wreszcie, gdy nie pomogło i zalewanie wapnem, postanowiono ewakuować tych niespokojnych mieszkańców cmentarza. Przez tydzień, mimo strzelaniny, wywożono ich po nocy samochodami i wywieziono co do jednego, lecz nie wywieziono [...] ziemi" [Kossowski 1963: 122].

Lucio Fabi podkreślił, że w tamtym okresie całe obszary ziemi przybierały wygląd swego rodzaju „wojska krzyży”, a niemal statyczny charakter wojny oraz ukształtowanie terenu w pobliżu gór Kras i rzeki Soczy pozwalały na tworzenie cmentarzy i ich systematyczną, naturalną ekspansję na skutek przedłużających się walk frontowych [Fabi 2007: 525]. Całe połacie ziemi przekształcały się więc w swego rodzaju cmentarzyska ze wszystkimi tego konsekwencjami, także i na przyszłość. Godna odnotowania jest w tym zakresie statystyka dotycząca tego właśnie terenu i sygnalizowanego problemu ${ }^{13}$ [Fabi 2007: 525-527].

$\mathrm{Na}$ te niesamowicie trudne warunki nakładały się dodatkowe uciążliwości związane ze stałymi atakami żołnierzy włoskich. Nieustanne ostrzeliwanie, bardzo często huraganowe i to w porze nocnej, czyniły niemożliwym wypoczynek. Polacy, chronicznie spragnieni snu („wielkie, okrutne zmęczenie”), stali się łatwym łupem

12 System ten został wprowadzony przez Niemców we wrześniu 1914 r. w walce nad Marną. Następnie zaadoptowano i rozwinięto go na szeroką skalę na froncie włoskim. Przed pierwszą linią frontu istniał obszar największego zagrożenia, określany mianem no man's land, następnie cały system obronny wydrążany w skałach ogromnym wysiłkiem. W 1916 r. odległość pomiędzy poszczególnymi okopami wynosiła nawet do 2-3 km, w ten sposób starano się stworzyć system o większej skuteczności obronnej.

13 Jak podał Fabi, w 1922 r. zlikwidowano 760 cmentarzy, ponad 1400 uporządkowano i poszerzono, wybudowano zaś ok. 30 nowych. Zebrano ponad 70000 rozrzuconych zwłok, odnaleziono 200000 grobów, zidentyfikowano ponad 2000 zabitych żołnierzy. 
dla wojsk przeciwnika. Zauważalna była też stała dyskryminacja żołnierzy z Podhala. Generalne dowództwo austriacko-niemieckie, kierując się zasadą oszczędzania pułków niemieckich, maksymalnie eksploatowało polskie dywizje, co w konsekwencji doprowadziło do ich zdziesiątkowania, tym bardziej że walka toczyła się w ekstremalnych warunkach: „ziemia się kolebała niby kołyska z niemowlętami”, [Kossowski 1963: 141], a ,granaty padały, przecinając powietrze z takim zgrzytem, jakby wagon żelaza z nieba leciał” [Kossowski 1963: 161], „,[1]udzie na posterunkach alarmowych i nawet pod samymi drutami zasypiali ze zmęczenia, mimo świadomości, że stoją, a raczej leżą o dwadzieścia czy trzydzieści metrów od nieprzyjaciela [...]. Pułk topniał z dnia na dzień - w chwili przybycia na miejsce pułk liczył 2500 żołnierzy, a teraz liczba ta zmniejszyła się drastycznie, że nie liczy nawet 1000 osób" [Kossowski 1963: 126].

Stałą trudnością stało się więc codzienne obcowanie ze śmiercią. Wcześniej człowiek dążył za wszelką cenę do wyeliminowania śmierci z krajobrazu, pejzażu życia, teraz osiągnęła ona swe apogeum, zbierając swe tragiczne żniwo. W związku z nowymi okolicznościami zmieniono także - jak podkreśliła Annette Becker - łacińską maksymę z Si vis pacem, para bellum na Si vis vitam, para mortem [Becker 2007: 473].

Nowela Kossowskiego wyposaża nas w cenne informacje z zakresu podejmowanych przez pułk czynności w trakcie trwania ofensywy, oczywiście dotyczy to pułków, które nie brały bezpośredniego w niej udziału, i tak np. bohaterzy zapisu autobiograficznego zostali zasypani i uwięzieni w kawernie na 60 godzin. Pisanie listów, które określano mianem ,biuletynów zdrowia”, pozwoliło żołnierzom choć na chwilę przenieść się w inną perspektywę czasoprzestrzenną. Każdy z żołnierzy dyktował oficerom, sierżantowi listy do rodziny, ale ich treść była ściśle kontrolowana przez dowódców, co wynikało z zakazu przekazywania bliskim zbyt tragicznych informacji ${ }^{14}$.

Informacje te są dla nas potwierdzeniem powszechnie stosowanych w okresie Wielkiej Wojny praktyk korespondencyjnych, obecnych na obszarze wszystkich frontów. W żadnej bowiem wojnie prowadzonej wcześniej linia podziału pomiędzy cywilami a walczącymi nie zaznaczyła się z taką intensywnością i gwałtownością. Jedyną formą utrzymania jakiegokolwiek kontaktu pozostawał więc przekaz listowy. Interesujące są też dane statystyczne, które uświadamiają nam ogrom przesyłanej w tamtym okresie korespondencji i warto ją tutaj, chociaż w części przytoczyć: w październiku 1914 r. poczta wojska angielskiego przesłała w jednym tygodniu 650000 listów i 58000 paczek; w 1916 r. na front wysłano w ciągu tygodnia prawie 11 milionów listów i 875000 paczek. W czasie trwania wojny na front z samych tylko Niemiec wysłano 28,7 miliarda listów, kart pocztowych, paczek i gazet. Średnia dzienna przesyłek na front to 9,9 miliona, a 6,8 miliona to przesyłki z frontu. We Włoszech liczba frontowych przesyłek wyniosła ok. 4 miliardy, przy dziennych

14 Podobną funkcję konsolacyjną spełniały praktyki religijne, tj. śpiew pieśni kościelnych, wielkopostnych, wielkanocnych i kolęd. 
przesyłkach w wysokości $1770000 \mathrm{w}$ czerwcu 1918 r. Informacje dotyczące poczty publikowano na pierwszych stronach gazet, a w wypadku jej niewłaściwego funkcjonowania sam cesarz pozostawał zobligowany do ich uregulowania [Duménil 2007: 211]. Korespondowanie, obok swego utylitarnego charakteru, było obostrzone klauzulą emocjonalności. Funkcja podtrzymania więzi rodzinnych, potwierdzenia bliskości uczuciowej, manifestacja i konsolidacja uczuć pomiędzy członkami pozostającymi w domu i tymi na froncie pozostawała powierzona w tym okresie właśnie przekazowi listowemu. Anna Duménil wskazała, że w ten sposób dochodziło do „podzielenia się doświadczeniem wojny” i jej „przetworzeniem na nowo" [Duménil 2007: 211]. Sam zaś fakt autocenzury albo cenzury zewnętrznej, który spotykamy i u Kossowskiego, był zjawiskiem praktykowanym na szeroką skalę. Poświęcenie żołnierza i jego tragizm to bowiem podstawa obrony cywilów, to swego rodzaju modus vivendi oraz zachowanie tych wszystkich wartości narodowych, duchowych i kulturowych, które całej zbiorowości ludzkiej pozostawały bliskie [Duménil 2007: 211].

Kossowski dostarczył nam unikalnego jak na tamte czasy i niezwykle interesującego opisu jednego $\mathrm{z}$ włoskich miast - Triestu. $Z$ opisu tego jednoznacznie wynika, że dominująca żądza ocalenia, przetrwania, choćby na chwilę, na jeden dzień, wypierały strach i pozwalały zapomnieć o tym, co tragiczne i bolesne w wojennej rzeczywistości. Tętniące życiem polis wśród ogromu necropolis przyciągało bowiem i pobudzało [Ligenza 1998: 62]: „A Triest, który nigdy nie był martwy, stał się w tym czasie jakąś wielką rzeką ludzi, uchodzącą olbrzymią deltą w morze i na front nad Isonzą. Przelewały się przezeń całe masy pułków, batalionów, kompanii, pociągów żywności, mundurów i amunicji, w porcie zaś bełtały gładką powierzchnię statki przenajróżniejszych kształtów i wielkości. Po ulicach dudniły samochody i wozy wojskowe, obładowane żywnością i jej surogatami. Chodniki były zawalone wojskowymi, używającymi świata przed dostaniem się na front lub po jego opuszczeniu. Najwięcej jednak hulali w tym najrozpustniejszym w owe czasy mieście ci, którzy zdołali ukraść wojnie dwa czy trzy dni. Ci szaleli wprost. Wyrzucali pieniądze w błoto, włócząc się w dzień i noc po knajpach i spelunkach, afiszując się pod rękę z rozhukanymi dziewczętami wszelkiej narodowości, myśląc jedynie o tym, by nasiąknąć uciechą, rozpustą, światłem, muzyką, tanim luksusem i podłym alkoholem znowu na kilka miesięcy. Włóczyło się to wszystko całymi dniami i w pełni światła po białym, złażonym z wielkich płyt bruku, napełniało gwarem, śmiechem i brzękiem ostróg najciaśniejsze uliczki, zalewało wielkie molo, pełne kawiarń, tawern i hoteli, z nastaniem nocy zaś ginęło w restauracjach, kinach, kawiarniach i kabaretach, by pić, póki starczyło sił i pieniędzy. Wtedy ulice zalegała cisza śmiertelna i ciemności zupełne. Gaszono światła i zasłaniano okna tak szczelnie, jakby od tego losy świata zależały. Bano się, by włoscy lotnicy nie chcieli gasić lamp bombami. Ot, struś schował łeb pod skrzydło i myśli, że go nie widzą, baa! zupełnie nie widzą, gdzie jest! [...] znikałem niekiedy na całą noc, pogrążałem się w tym, co Triest mi dać mógł, chłonąłem światło, gwar, zapach ciał i wściekłą żądzę życia i wracałem nad ranem" [Kossowski 1963: 166-167]. 
Jay Winter w swojej pracy Le città analizie poddał przestrzenie miejskie podczas trwania Wielkiej Wojny. Zauważył, że uległy one „nacjonalizacji”, tj. zatraciły swój regionalny i lokalny charakter, zyskując tym samym wymiar międzynarodowych aglomeracji. Wszelka egzystencja sprowadzała się w nich do wymiaru wojennego i pozostawała naznaczona walką o przetrwanie [Winter 2007: 65]. Autor tekstu zastosował linię demarkacyjną, dokonał rozgraniczenia na miasta położone daleko od frontu i na te, które musiały się zmierzyć z agresją wojsk nieprzyjaciela. Jakkolwiek to miasta, a nie obszary wiejskie głównie ucierpiały na skutek wojny [Winter 2007: 72-73]. Przykład Triestu jest w tym kontekście wyjątkowy, bliskość frontu nie przyprawia o trwogę, przeciwnie - stanowi silny bodziec, aby wyrwać życiu choćby tylko jego namiastkę, aby choć na chwilę zapomnieć o tragizmie rozpisanym na polach walk w niedalekiej odległości. Lucio Fabi podkreślił, że w okresie Wielkiej Wojny Triest był miastem-symbolem całego ówczesnego konfliktu. Usytuował je na płaszczyźnie artystycznej, wśród zabytków i pomników miasta, można też było tam obejrzeć ,,bogatą kolekcję Henriquez'a” [Fabi 2007: 525].

Jeden z zapisków Kossowskiego, szczególnie cenny i interesujący moim zdaniem, traktuje o realnym zagrożeniu zbombardowania centrum Wenecji, a dokładniej serca Serenissima, tj. Bazyliki św. Marka wraz z jej placem, przez węgierskiego pilota Hodasa i jego udaremnieniu właśnie przez Kossowskiego. Hodas należał do doskonałych pilotów, strącił bowiem 26 samolotów nieprzyjacielskich i mimo swej orientacji antyaustriackiej, głośno artykułowanej, powierzano mu wykonywanie zadań najtrudniejszych i wymagających ogromnej precyzji.

Notabene wiadomo, że kiedy 23 maja 1915 r. ambasador Włoch w Wiedniu, zdecydowany przeciwnik wojny z Austro-Węgrami, złożył wizytę w austriackim Ministerstwie Spraw Zagranicznych i wręczył akt wypowiedzenia wojny, wczesnym rankiem następnego dnia austriacka marynarka rozpoczęła działania wojenne, ostrzeliwując kilka nadmorskich miejscowości, a nieliczna grupa austriackich samolotów zbombardowała właśnie Wenecję [Jordan 2001: 113-114]. Nie doszło jednak do nalotów na samo jej centrum, jakkolwiek lotnictwo austro-węgierskie dokonywało codziennych, regularnych lotów patrolowych nad terytorium Włoch. Uczestniczył w nich właśnie Kossowski.

Wiadomo także, że w chwili wybuchu Wielkiej Wojny lotnictwo austriackie nie posiadało prawie zupełnie samolotów i dysponowało znikomą liczbą wyszkolonych pilotów, a wszelkie poczynania Milana Uzelacza, którego matka była Polką, nie mogły wpłynąć na zmianę tego faktu. Przyczyniły się do tego także inne okoliczności, a mianowicie seryjna produkcja rodzimych Lohneów okazała się być niczym innym jak wielką porażką, a słynna katastrofa z 20 czerwca 1914 r. w Wiener-Neustadt doprowadziła do wycofania się ze służby ogromnej liczby niedoszłych lotników [Zaręba 2004: 23]. W takiej sytuacji tolerowano nawet antyaustriackie zachowania niektórych z węgierskich lotników, w tym Hodasa. Kossowski odnotował w swoich zapiskach: „Raz wieczorem doręczono mi książkę z rozkazem, że lecę o godzinie trzeciej trzydzieści rano z porucznikiem-pilotem Hodasem (właśnie z nim!) wprost 
na Wenecję. Wenecji zawsze byłem ciekaw, alem nigdy nie myślał, że zobaczę ją po raz pierwszy [...] z góry, lotu ptaka [...] Ta bestia gotowa wylądować na placu Świętego Marka!" [Kossowski 1963: 100].

Baza lotnicza armii austro-węgierskiej znajdowała się w miejscowości Volčji Grad położonej na „skalistej górze”, gdzie lotnicy zajmowali „ciemne, kamienne słoweńskie domy, dające miły chłód w spiekłe dni lipcowe" [Kossowski 1963: 96].

Jerzy A.T. Kossowski zauważył, że po bokach samolotu zawieszono bomby i lot miał na celu zrzucenie ich na włoską ziemię. Autor Zielonej kadry w sposób szczegółowy opisał trasę przelotu nad Krasem, a następnie nad Tagliamento i w korytarzu powietrznym Monfalcone-Wenecja. Jednak to, co prześladuje Polaka podczas lotu, to nieustanna obawa, gdzie Hodas zamierza zrzucić bomby. Opis eskalujący napięcie i oddający powagę tamtej chwili zasługuje w pełni na przytoczenie w całości: „Czy Hodas rzuci bomby na Wenecję, czy nie? Czy się zdobędzie na to, by zatoczywszy nad cudnym miastem łuk, wrócić, nie niszcząc świętości? [...] Wylecieliśmy już ponad Porto di Lido. Ogień się wzmógł [...] O dwa tysiące metrów przed sobą widziałem wyspę S. Pietro z wielkimi koszarami, a za nią całą wschodnią połać Wenecji [...] Zboczyliśmy trochę w lewo i nad szachownicą niebieskich kanałów dopływaliśmy do placu Świętego Marka [...] W lewo wskroś błyszczał pod nami Canale di Marco, a za nim wyspa di S. Giorgio Maggiore. Zorientowałem się: Jezu! za parę sekund będę miał przed sobą Palazzo Ducale! Pałac Dożów, o którym lata marzyłem, że go zobaczę. Boże! Tak! Oto widzę dwa słupy granitu stojące na końcu Piazzy i w gorączce podniecenia widzę brązowego uskrzydlonego lwa świętego Marka i statuę świętego Teodora. Boże! Campanilla! Więc Hodas chciałby?... Właśnie tu? W Pałac Dożów? Może właśnie w przecudne Scala degli Giganti?! Spojrzałem na Hodasa: przełożył rękę na lewy hebel, opuszczający bomby. Zaparło mi dech: Jak to? Więc on by śmiał?! Rzuciłem się naprzód i wyrznąłem go kułakiem w plecy, że aż się pochylił nad wolanem. Obejrzał się. Złożyłem ręce jak do modlitwy i począłem wrzeszczeć, choć wiedziałem, że nie usłyszy w huku motoru i śmigi: Ulituj się! Nie rzucaj! Nie bądź łotrem! Ulituj się! Patrzył mi długą chwilę w oczy, a ja byłem przygotowany na to, że jeśli rzuci bomby, wtedy ja palnę mu z pistoletu w łeb. Niechby się potem co chce działo, niechby aparat runął z nami w powietrzną przepaść! Ale Hodas uśmiechnął się i powoli rękę z hebla cofnął. Przechyliłem się [...] i wyciągnąłem do niego dłoń. Podał mi lewą rękę i nie zdołał jej cofnąć, kiedym przycisnął do niej usta. [...] Lecieliśmy w prawo. Myślałem, że Hodas zechce obłożyć bombami dworzec kolejowy, magazyny, a może przecudne jak koronka $\mathrm{z}$ dala błyszczący olbrzymi most Ponte Sulla Laguna, łączący Wenecję z Mestre na lądzie stałym. Ale nie. Lecieliśmy parę sekund nad Canale Grande w kierunku Ponte di Rialto. Zatrząsł mną znowu strach, że Hodas zechce zbombardować pałac poczty. Ale nie. Aparat zataczał wielki łuk i zwrócił się ku Murano, po czym - prawie tą samą linią ponad Porto di Lido, wypalił nad morze. [...]. Byliśmy już prawie na linii ujścia Piawy, widocznej w odległości jakich dwudziestu kilometrów, gdy Hodas [...] położył obydwie łapy na heblach od bomb i pociągnął równocześnie. Widziałem, 
jak cztery bomby wpadły w morze niby jedna, jak na chwilę wybuchła tam w dole, w jednym tylko miejscu, straszna burza i jak po pewnym czasie uspokoiło się łono morskie, kryjąc naszą wspólną tajemnicę" [Kossowski 1963: 110-112].

\section{ZAKOŃCZENIE}

Analiza powyższego materiału źródłowego ewokuje problematykę Wielkiej Wojny, która sytuuje się w perspektywie dwupłaszczyznowej. Z jednej strony przytoczone teksty są potwierdzeniem powszechnie utrwalonych w literaturze przedmiotu opinii na temat tego, czym był ten historyczny konflikt ${ }^{15}$, w jaki sposób zmienił oblicze dziewiętnastowiecznego świata [Pajewski 1991: 783] i dlaczego doprowadził do ,tajemniczej wewnętrznej przemiany całej ludzkości” [Dębicki 1914: 42].

Z drugiej strony zaś, zawężając kontekst interpretacyjny, zapiski autobiograficzne ilustrują wydarzenia, historie, losy polskich żołnierzy walczących na froncie włoskim. To, co uderza w tych tekstach, to afirmacja życia bez względu na spowijające wszystko okowy śmierci, to fascynacja pięknem mimo przemożnej dominacji brzydoty i okaleczenia, to wreszcie próba ocalenia tego, co w wyobraźni kolektywnej jest określane mianem mitu Italii. O istotnej wartości powyższych tekstów stanowią same czyny ich autorów, drobne gesty codziennej heroiczności (postawa Bergera) czy spektakularne osiągnięcia (postawa Kossowkiego), dzięki którym Wenecja ze swym pięknem architektonicznym i kulturowym nie przestała istnieć. Powyższe teksty ujawniają fakty o szczególnej doniosłości historycznej, mianowicie podkreślają istotny wkład polskiego żołnierza w dzieje bitew, walk czy zwycięstw prowadzonych na froncie włoskim, zarówno w wymiarze jednostkowym, jak i kolektywnym.

\section{BIBLIOGRAFIA}

Alonge, G. 2007. La Grande Guerra e il linguaggio cinematografico, [w:] La prima guerra mondiale, S. Audoin-Rouzeau, J.J. Becker (red.), Giulio Einaudi editore, Torino.

Audoin-Rouzeau, S. 2007. Le trincee, [w:] La prima guerra mondiale, S. Audoin-Rouzeau, J. J. Becker (red.), Giulio Einaudi editore, Torino.

Basil, H. Liddell Hart. 2014. La prima guerra mondiale 1914-1918, F. Perfetti (wstęp), BURRizzoli, Milano. Batowski, H. 1982. Rozpad Austro-Węier 1914-1918. Sprawy narodowościowe i działania dyplomatyczne, Wydawnictwo Literackie, Kraków.

Becker, A. 2007. Il culto dei morti tramemoria e oblio, [w:] La prima guerra mondiale, S. Audoin-Rouzeau, J.J. Becker (red.), Giulio Einaudi editore, Torino.

Berger, K. 1930. Na Podgorze. Garść wspomnień frontu włoskiego, nakład autora, Czeski Cieszyn.

15 Kleiner podkreślił, iż wojna ta „okazała się czymś bardziej nowym i niespodziewanym, czymś potężniejszym, ogromniejszym i straszniejszym nad wszystko, cokolwiek w świecie swoim zdziałał i poznał duch ludzki. W dotychczasowym systemie myślenia nie było dla niej miary" [Kleiner 1981: 79]. 
Bianchi, B. 2001. La follia e la fuga. Nervosi di guerra, diserzione e disobbedienzanell'esercitoitaliano 1915-1918, Bulzoni Editore, Roma.

Cygan, W.K. 2005. Oficerowie Legionów Polskich 1914-1917. Stownik biograficzny, t. 1, A-F, Wydawnictwo „Barwa i Broń”, Warszawa.

Dębicki, Z. 1914. Przemiany, „Tygodnik Ilustrowany” 708.

Duménil, A. 2007. I vivi e imorti. I combattimenti, [w:] La prima guerra mondiale, S. Audoin-Rouzeau, J.J. Becker (red.), Giulio Einaudi editore, Torino.

Duménil, A. 2007a. Una guerrasensata. I combattimenti, [w:] La prima guerra mondiale, S. Audoin-Rouzeau, J.J. Becker (red.), Giulio Einaudi editore, Torino.

Eksteins, M. 1996. Święto wojny. Wielka wojna i narodziny nowego wieku, K. Rybińska (tłum.), Państwowy Instytut Wydawniczy, Warszawa.

Fabi, L. 2007. Territorio e memoria. Il fronteitalo-austriaco, [w:] La prima guerra mondiale, S. Audoin-Rouzeau, J.J. Becker (red.), Giulio Einaudi editore, Torino.

Gilbert, M. 1994, Pierwsza wojna światowa, S. Amsterdamski (tłum.), Zysk i S-ka, Poznań

Giza, J. 2011. Organizacja ,Wolność” 1918. Polska konspiracja niepodległościowa w cesarsko-królewskiej armii podczas I wojny światowej i losy jej bohaterów, Wydawnictwo Jerzy Giza, Kraków.

Guerrini, I. Pluviano, M. 2004. Le fucilazioni sommarie nella prima guerra mondiale, Paolo Gaspari Editore, Udine 2004.

Horoszkiewicz, W. 1938. Na Monte Tomba, „Żołnierz Legionów i POW” 34-36.

Hupka, J. 1936. Z czasów Wielkiej Wojny. Pamiętnik nie kombatanta, nakładem autorem, Niwiska.

Jordan, D. 2001. Historia I wojny światowej, Bałkany, Włochy i Afryka 1914-1918, od Sarajewa do Piawy i Jeziora Tanganika, D. Showalter (wstęp), J. Szkudliński (tłum.), Dom Wydawniczy Rebis, Poznań.

Kleiner, J. 1981. Pod wrażeniem wojny $i$,, Księgi ubogich”, [w:] W kręgu historii i teorii literatury, A. Hutnikiewicz (red.), Wydawnictwo PWN, Warszawa.

Kossowski, J. 1963. Zielona Kadra, Ludowa Spółdzielnia Wydawnicza, Warszawa.

Koźniewski, K. 1963. Posłowie, [w:] J. Kossowski, Zielona Kadra, Ludowa Spółdzielnia Wydawnicza, Warszawa.

Kucharski, W. 1991. Polacy w rdzennej Austrii w czasie I wojny światowej oraz ich udział w odzyskaniu przez Polskę niepodległości w 1918 roku, [w:] Polonia i odbudowa państwa polskiego w 1918 roku, W. Śladkowski (red.), Wydawnictwo UMCS, Wydawnictwo Polonia, Warszawa-Lublin.

Labanca, N. 2007. La guerra sul fronte italiano e Caporetto, [w:] La prima guerra mondiale, S. Audoin-Rouzeau, J.J. Becker, (red.), Giulio Einaudi editore, Torino.

Leoni, D. 2007. Guerra di montagna/Gebirgskrieg, [w:] La prima guerra mondiale, S. Audoin-Rouzeau, J.J. Becker (red.), Giulio Einaudi editore, Torino.

Lewandowski, J. 1991. „Z ziemi obcej do Polski” - powroty do kraju (1914-1929), [w:] Polonia i odbudowa państwa polskiego w 1918 roku, W. Śladkowski (red.), Wydawnictwo UMCS, Wydawnictwo Polonia, Warszawa-Lublin.

Ligenza, W. 1998. Jerozolima i Babilon. Miasta poetów emigracyjnych, Wydawnictwo Baran i Suszczyński, Kraków.

Olszewska, M.J. 2004. Człowiek w świecie Wielkiej Wojny. Literatura polska z lat 1914-1919 wobec I wojny światowej. Wybrane zagadnienia, Wydawnictwo Wydziału Polonistyki UW, Warszawa.

Pajewski, J. 1991. Pierwsza wojna światowa 1914-1918, Wydawnictwo PWN, Warszawa.

Popiołek, Z. 1928. Z obozu w Szeklencze na front włoski, [w:] Za kratami więzień i drutami obozów, nakład Komitetu Organizacyjnego Wjazdu B. Więźniów Ideowych, Warszawa.

Rozmus, J. 2013. Żotnierskie narracje o wojnie światowej 1914-1918. Strzelcy, legioniści, Polacy w armii austro-węgierskiej, Wydawnictwo UP, Kraków.

Rydel, J. 2000. W stużbie cesarza i króla, Księgarnia Akademicka, Kraków.

Snopko, J. 2008. Finat epopei Legionów Polskich 1916-1918, Wydawnictwo Uniwersytetu w Białymstoku, Białystok.

Solek, W. 1988. Pamiętnik legionisty, Wydawnictwo PAX, Warszawa. 
Stępnik, K. 1997. Rekonesans. Studia z literatury i publicystyki okresu I wojny światowej, Wydawnictwo UMCS, Lublin.

Święch, J. 2003. Wojna a „projekt nowoczesności”, [w:] Modernistyczne źródta dwudziestowieczności, M. Dąbrowski, A.Z. Makowski (red.), Warszawa.

Traverso, E. 2007. Sentimenti nazionali e terre irredente, [w:] La prima guerra mondiale, S. Audoin-Rouzeau, J.J. Becker (red.), wersja włoska A. Gibelli (red.), Giulio Einaudi editore, Torino.

Wielgus, K. 2004. Wstęp czyli o lotniczym przewodniku po zaginionym świecie, [w:] A. Zaręba, Orly Habsburgów. Mały przewodnik po cesarskim i królewskim lotnictwie Austro-Węgier, Biuro Usług Komputerowych Stanisława Smaga, BUKSS, Dębica.

Winter, J. 2007. Le città, [w:] La prima guerra mondiale, S. Audoin-Rouzeau, J.J. Becker, (red.), Giulio Einaudi editore, Torino.

Winter, J. 2007. Le vittime: morti, feriti e invalidi, [w:] La prima guerra mondiale, S. Audoin-Rouzeau, J.J. Becker, (red.), Giulio Einaudi editore, Torino.

Wyszczelski, L. 2001. Polskie wojskowe formacje regularne w czasie I wojny światowej, [w:] A. Kołodziejczyk, K. Pindel, Rok 1918 na Podlasiu, Instytut Historii Akademia Podlaska, Siedlce.

ITALIAN FRONT OF THE GREAT WAR IN AUTOBIOGRAPHICAL WRITINGS OF KAROL

\section{BERGER AND JERZY ALFRED TOMASZ KOSSOWSKI}

Abstract: The Great War was the 'armed conflict that radically altered the face of the $19^{\text {th }}$ century world'. The old order of peace and hope lay in ruins. Of all that had seemed permanent and immutable, nothing had been restored to its former place, because things no longer had 'their place'. When war broke out, Poland was without statehood, partitioned between Russia, Germany and Austria. Polish men of fighting age could not choose sides independently, but were conscripted on a territorial basis into the armies of the partitioning states, and thus many found themselves on opposite sides of the firing line, killing each other. Nonetheless, the fact that the 1914-1918 war was the first to involve directly all three partitioning states kindled profound hopes among the Polish people of regaining independence. Service in the Austro-Hungarian army did not initially bring discredit upon Poles, thanks to the policies upheld by Vienna, but later attitudes changed dramatically. In their autobiographical eye-witness reports of the fighting on the Italian front, Karol Berger and Jerzy Alfred Kossowski give us a detailed account of all the tragic, harsh realities of war. At the same time, Berger is perceptibly at pains to tone down the ferocity, to present war with as human a face as he is able, to create at least a surrogate of life and shared human existence. Kossowski, on the other hand, was a pilot, the man who prevented the bombing of the heart of Venice, St. Mark's Square and Basilica, during the First World War. Their writings make clear how both men held the myth of Italy dear, striving not to be crushed by the machinery of evil, and also, whether through small gestures (Berger) or spectacular decisions (Kossowski), how both were able to dominate 'the indomitable'.

Keywords: Italian front, the Great War, Karol Berger, Jerzy Alfred Tomasz Kossowski

\section{BIOGRAM}

Iwona Dorota, pięciokrotna stypendystka Rządu Włoskiego, stypendystka Instytutu Kultury Włoskiej i Ministerstwa Spraw Zagranicznych. Odbyła kilkuletni staż naukowy w Instytucie Slawistyki (Uniwersytet w Weronie). Obecnie pracuje na Uniwersytecie w Mediolanie (Dipartimento di Studi Linguistici, Letterari e Filologici) jako profesor kontraktowy; w kwietniu 2016 r. otrzymała status ,naukowca 
obcokrajowego" (studiosa straniera). Jej zainteresownia badawcze koncentrują się głównie wokół literatury romantycznej, a w szczególności korespondencji Zygmunta Krasińskiego (rozprawa doktorska zatytułowana Włoskie imaginatorium w epistolografii Zygmunta Krasińskiego). Uczestniczyła w wielu kongresach światowych naukowych, literackich i historycznych. Autorka licznych publikacji z zakresu literatury porównawczej, współpracuje z wieloma czasopismami naukowymi na terenie Włoch, Polski i Francji, m.in. z „Centro Interuniversitario di Ricerche sul Viaggio in Italia (CIRVI)" z siedzibą w Turynie, gdzie opublikowała m.in. pięć tomów korespondencji włoskiej Zygmunta Krasińskiego:

1. Zygmunt Krasiński, Lettere dall'Italia. Il Sud, Moncalieri 2008;

2. Zygmunt Krasiński, Lettere dall'Italia. Viaggi giovanili, Moncalieri 2009;

3. Zygmunt Krasiński, Lettere dall'Italia. Roma. Lettere a Delfina Potocka, Moncalieri 2011;

4. Zygmunt Krasiński, Lettere dall'Italia. Roma. Lettere agli amici, Moncalieri 2011;

5. Zygmunt Krasiński, Testimonianze poetiche del'48, Moncalieri 2011.

Pierwsza z publikowanych pozycji została umieszczona w Stanach Zjednoczonych Ameryki na liście „The best book buys” (2008). Trzy ostatnie tomy ukazały się w serii wydawniczej: „Wielkie Książki 150 Rocznicy Zjednoczenia Włoch”. Od kwietnia 2012 r. jest członkiem "Centro Interuniversitario di Ricerche sul Viaggio in Italia” (CIRVI), jest też ponadto członkiem Stowarzyszenia Polonistów Włoskich. Kontakt e-mail: iwona.dorota@unimi.it. 